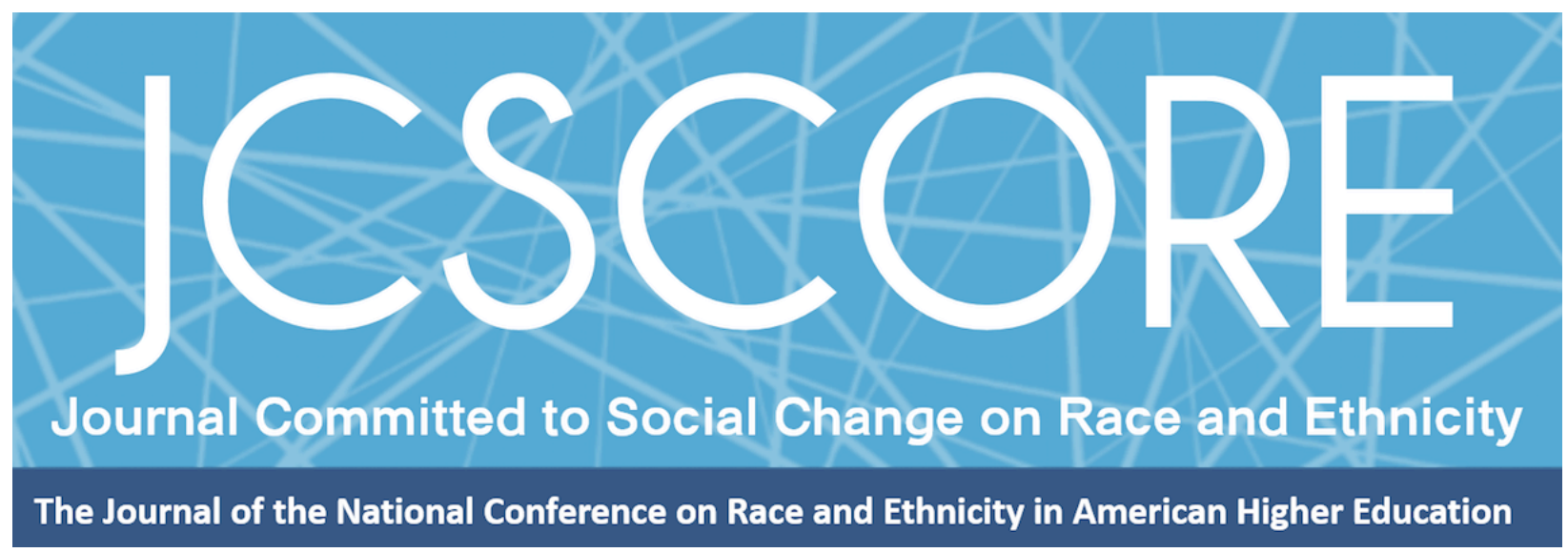

\title{
COMPLICATING THE BINARY: TOWARDS A DISCUSSION OF CAMPUS CLIMATE HEALTH
}

María C. Ledesma

University of Utah

Journal Committed to Social Change on Race and Ethnicity

Volume 2, Issue 1 | 2016

Copyright $\odot 2015$ Board of Regents of The University of Oklahoma on behalf of the Southwest Center for Human Relations Studies.

Permission of the Publisher is required for resale or distribution and for all derivative works, including compilations and translations. Quoting small sections of text is allowed as long as there is appropriate attribution. 


\section{Complicating the Binary: Towards a discussion of Campus Climate Health}

María C. Ledesma

University of Utah

In this conceptual paper, I embark on answering the question "is there a more nuanced way of helping postsecondary leaders, practitioners, and policy makers understand the gravity of addressing and confronting issues of campus climate?" In response, I propose that it may prove useful when framing issues of campus climate to complicate binary descriptions of climate as "chilly/welcoming" and "positive/negative," and instead embrace the analogy of health. While the adoption of a metaphor of healthy campus climate is not novel per se, it remains under-theorized. As such, this paper aims to contribute to the conversation around diversity and campus climate by suggesting that a health metaphor applied to the study of campus climate is apropos and helps humanize the experiences of historically minoritized bodies in higher education.

Terms like "campus climate" and "microaggressions" have become increasingly common phrases in our everyday vernacular. ${ }^{1}$ Today mainstream and non-traditional media outlets alike make regular mention of these topics, terminology previously restricted to research literature and higher education nomenclature. However, this is no longer the case. A resurgence of student protest and activism has helped bring the issues of campus climate and microaggressions to the fore. As Johnston (2015) observed, "Contemporary student protest has arisen in response to myriad issues, both local and national, but three main topics stand out: racial discrimination, sexual assault

\footnotetext{
Author Note: I am grateful for the helpful commentary provided by Dolores Calderon and Uma Jayakumar on early versions of this article. I also thank JCSCORE editors and reviewers for their careful feedback.

${ }^{1}$ The usage and frequency of the terms microaggressions and campus climate in the public narrative has been on the rise in the last few years, precipitated by local and national events, including the televised spectacle of police brutality against bodies of color. Some examples showcasing the adoption of these concepts in public narrative include the following: http://www.huffingtonpost.com/john-fitzgerald-gatesphd/institutionalized-racism_b_7130822.html; http://www.huffingtonpost.com/nashwa-lina-
} 
and harassment, and rising tuition and student debt" (Johnston, 2015, p. B6). And while all students are potentially susceptible to being adversely affected by these issues, historically underrepresented students "... have been brought to a crisis" (p. B6). Of course these crises did not occur overnight (Harper \& Hurtado, 2007); rather, they are the by-product of longstanding grievances too often coupled with institutional inaction and neglect. Indeed, despite over three decades of scholarly literature on the importance of recognizing and addressing the complexities of campus climate, especially for historically minoritized communities, postsecondary institutions continue to lag behind in responding to the differential needs and realities of historically underrepresented populations in higher education.

In this conceptual paper, I embark on posing the question "is there a more nuanced way of helping postsecondary leaders, practitioners, and policy makers understand the gravity of addressing and resolving diversity related campus climate issues?" In response, I propose that it may prove useful when framing issues of campus climate to complicate existing binary descriptions of climate as "chilly/welcoming" and "positive/negative," by embracing the metaphor of health-such as striving for a healthy climate or remedying an unhealthy climate. Such a reframing not only builds off a robust body of research literature, it also suggests that when a problem is diagnosed, treatment is a necessary next step.

I begin this exercise by situating the contemporary conversation on campus climate within larger historical context. With the aid of critical race theory, I briefly delve into the proliferation of campus climate research in higher education. By tracing the roots of diversity-oriented campus climate literature, I aim to recover and recouple how 
the study of campus climate not only analyzes the power and impact of systemic and structural white supremacy and racism on institutional and individual norms and values, but how these in turn affect the physical and mental health of participants and institutions alike. To support why coupling campus climate with health makes sense, I provide analysis on the well-documented role of racism on health. Finally, I posit that as applied to the study of campus climate, the adoption of a health metaphor aims to humanize the experiences of historically minoritized bodies in higher education. And while I recognize that all marginalized identities are vulnerable in relation to majoritarian norms and values, for the purpose of this paper I focus specifically on racial/ethnic diversity, and more specifically on the impact of race and racism in higher education.

\section{The Myth of Postraciality and the Postsecondary Context}

A decade and a half into the twenty-first century, the study and examination of race and racism remains central to postsecondary scholarship (Dowd \& Bensimon, 2015; Gutiérrez y Muhs, Neimann, Gonzalez, \& Harris, 2013; Harper, 2012; Museus, Ledesma, \& Parker, 2015; Smith, 2011, 2015). Declarations of post-racialism ushered in by the two-term election of President Barack Obama have proven premature (Goldberg, 2015; López, 2010). To the contrary, organizations like the Southern Poverty Law Center have documented the steady rise of White supremacist antigovernment hate groups, which grew in the wake of the election of the Nation's first African American President (Potok, 2016). In addition, Gallup recently reported that, for the first time in more than a decade and for the first time since the 1992 unrest following the Rodney King verdict, $13 \%$ of Americans named racism as the most important U.S. problem (Riffkin, 2015). Contrary to what some might have us believe (McWhorter, 2008, 2010), 
Journal Committed to Social Change on Race and Ethnicity | 2016

these occurrences are not anomalies but rather contemporary manifestations of the long history of white supremacy and racism, upon which the nation and all of its institutions, including higher education, were founded (Karabel, 2005; Marable, 2002; Omi \& Winant, 1994, 2015; Thelin, 2004).

Critical race theory (CRT) posits that racism is normal and endemic (Bell, 1980, 1987, 1989, 1991, 1992, 2004, 2005a, 2005b; Crenshaw, 2011; Crenshaw, Gotanda, Peller, \& Thomas, 1995; Delgado \& Stefancic, 2012). In the study of higher education, critical postsecondary scholars confirm that race and racism continue to influence how historically minoritized groups experience higher education (Carnevale \& Strohl, 2013; Feagin, Vera, \& Imani, 1996; Steele, 1999, 2010). Even so, general reticence remains in naming and addressing racism's permanence in the postsecondary context (Harper, 2012; Museus, Ledesma, \& Parker, 2015). The end of de-jure, state sanctioned, racial discrimination coupled with the rise of neoliberalism and colorblindness (Bonilla-Silva, 2003; Goldberg, 2015) help fabricate and perpetuate a myth of postraciality. However, as Goldberg (2015) clarifies postraciality is not the same as post-racism, or said differently, postraciality is not the same as anti-racism. While postraciality obscures the realities of "institutionalized violence, alienation, and excision" (Goldberg, 2015, p. 122), anti-racisms "actively and assertively refuse to take for granted the conditions for which racisms stand [as] somehow naturalized and ahistorical inevitabilities and irreversibilities" (p.169). If we are not post-racial, we continue to be racial—living in a world where race and racism still matter, and higher education is certainly no exception. Ironically, rather than quell racial tensions, persistent assertions in support of race-neutrality and colorblindness, including the well-funded campaign to end race- 
Journal Committed to Social Change on Race and Ethnicity | 2016

conscious affirmative action, have only served to heighten issues of race and racism on college and university campuses (Yosso, Parker, Solórzano, \& Lynn, 2004). Although opponents of race-conscious affirmative action have purported that ending said policies would end racial bias and discrimination (Kahlenberg, 1997; Thernstrom \& Thernstrom, 1997), evidence suggests otherwise. In California, Florida, Michigan, and Washington, all states with voter-approved referenda to end affirmative action practices, racial tension and educational disparities continue to persist across the PK-20 pipeline (Grodsky \& Kurlaender, 2010; Kidder \& Gándara, 2015; Long, 2007; Long \& Tienda, 2008). These facts coupled with an increasingly fractured socio-political system, rising tension and unease concerning economic inequity, and an onslaught of flagrant police brutality against people of color (Sheriff, 2015), all combine to frame and shape today's contemporary college experience. Colleges and universities are, after all, a reflection of their surroundings (Hurtado, Alvarez, Guillermo-Wann, Cuellar, \& Arellano, 2012; Hurtado \& Alvarado, 2015; Manning, 2013). Postsecondary institutions do not operate in a vacuum, rather they are influenced and shaped as much by what happens within their walls as by what happens across the local, regional, and national landscape.

It is no coincidence then that the nation's college campuses served as the epicenter for one of the most important social movements in recent memory. The Black Lives Matter movement—borne out of the leadership efforts of Patrisse Cullors, Alicia Garza, and Opal Tometi-was inspired by the actions of Ferguson, Missouri residents demanding justice in the death of unarmed teenager Michael Brown. The national and international attention garnered by the high profile deaths of Black men and boys, including Brown, Oscar Grant, Trayvon Martin, Jordan Davis, Eric Gardner, Tamir Rice, 
Freddie Gray, and countless others—often at the hands of law enforcement officershelped catalyze a movement on city streets and college campuses. ${ }^{2}$ College students proved to be among the loudest voices in the groundswell of support against state violence and police brutality. Motivated by a quest to "end systemic and structural racism" (WeTheProtestors, 2015), historically minoritized students were prompted to document their grievances, demanding change and justice from postsecondary institutions perceived to be bias and unresponsive to their needs. ${ }^{3}$

Perhaps the most prominent example of student protest took place at the University of Missouri, just 120 miles from Ferguson—scene of Michael Brown's contentious death. While student protest at Mizzou would ultimately lead to the resignation of University President Tim Wolfe, it would not be before exposing deeply entrenched racial tensions at Mizzou and colleges across the country (Berrett \& Hoover, 2015). In the aftermath of Mizzou and the student movement built in its wake, institutions are scrambling to respond to charges of disenfranchisement and neglect alleged by their historically minoritized students.

For both postsecondary students and campus leaders and administrators, existing campus climate research literature is a pivotal resource for understanding how campus race relations influence academic achievement, social involvement, and students' overall collegiate experience (Hurtado, 1992; Hurtado, Milem, Clayton-

\footnotetext{
${ }^{2}$ In the wake of the increased attention to the victims of state violence, including the death of Sandra Bland, the African American Policy Forum established the \#SayHerName campaign. Lead by co-founder and Critical Race Theory legal scholar Kimberlé Crenshaw, the \#SayHerName campaign is intended on bringing attention to growing incidences of police brutality against Black women, who are too often overlooked or forgotten victims of police brutality. See http://www.aapf.org/sayhernamereport/ ${ }^{3}$ One of the tangible byproducts of Black Lives Matter movement was the production and compilation of lists of student demands from close to 80 postsecondary institutions. A cross section of students, led by African American students and allied groups, from four year comprehensive institutions, small liberal arts colleges, as well as research intensive universities produced lists of demands specific to their campus histories and needs. All 79 lists may be found at http://www.TheDemands.org/
} 
Pedersen, \& Allen, 1998, 1999; Hurtado, Alvarez, Guillermo-Wann, Cuellar, \& Arellano, 2012; Milem, Chang, \& Antonio, 2005). In addition to validating students' experiences, this critical scholarship confirms the permanence of race and racism in academia while giving voice to those too often marginalized and/or silenced by majoritarian power structures. While detailing the exhaustive body of research literature on campus climate is beyond the scope of this paper, in the following, I will concentrate on highlighting a few key functions of campus climate scholarship to illustrate its evolution as well as its constancy.

\section{The Study of Campus Climate in Higher Education}

Jayakumar and Museus (2012) posit that while the terms campus climate and campus culture are often used interchangeably, there is value in understanding how these concepts differ. Citing Bauer (1998), they explain that campus climate is defined as "current perceptions, attitudes, and expectations that define the institution and its members" (Jayakumar \& Museus, 2012, p. 4). Whereas, citing Kuh and Hall (1993), they define campus culture as,

the collective, mutually shaping patterns of institutional history, mission, physical settings, norms, traditions, values, practices, beliefs, and assumptions that guide behavior of individuals and groups in an institution of higher education which provide a frame of reference for interpreting the meanings of events and actions on and off campus. (Jayakumar \& Museus, 2012, p. 6)

As early as 1935, Du Bois hinted at the need to differentiate and understand the multidimensional experiences of minority students on college campuses. Indeed, long before the formal study of "campus climate" was coined Du Bois recognized that institutional climate and culture are critical to fostering constructive educational settings for historically disenfranchised students. For the purpose of this paper, I focus on the 
Journal Committed to Social Change on Race and Ethnicity | 2016

concept of campus climate. However, I propose that my suggested re-framing of campus climate narratives is also applicable to discussions of campus culture.

While Jayakumar and Museus (2012) observe that higher education scholars have written about campus culture for decades, the proliferation of research literature focused on addressing racial disparities in higher education, including issues of campus climate, can be attributed to a series of events converging in the last three decades. The divestment of public funding in higher education, the rise and mainstreaming of neoliberalism and colorblindness_-including a concerted campaign to end raceconscious affirmative action policies in higher education—helped inspire the production of rigorous scholarship to mitigate the (mis)information driving a wide-scale assault on diversity.

For example, in response to the state ballot initiative movement, which early on produced California's Proposition 209 (1996) and Washington state's Initiative 200 (1998)—prohibiting the use of race-conscious practices in public higher educationcritical postsecondary scholars focused their efforts on producing rigorous and compelling research literature to showcase the civic and pedagogical benefits of diverse learning environments (Antonio, 2001, 2004; Antonio, Chang, Hakuta, Kenny, Levin, \& Milem, 2004; Chang, Denson, Saenz, \& Misa, 2006; Gurin, Dey, Hurtado, \& Gurin, 2002; Hurtado, 2001; Jayakumar, 2008; Orfield, 2001; Orfield \& Miller, 1998). This work only intensified as the challenge against affirmative action moved from the ballot box to the courtroom with Hopwood v. Texas (1996) as well as with the University of Michigan's affirmative action cases, Gratz v. Bollinger (2003) and Grutter v. Bollinger 
Journal Committed to Social Change on Race and Ethnicity | 2016

(2003), and more recently Fisher v. University of Texas (2013) and the pending Fisher v. University of Texas /l case.

Early scholarship on campus climate focused explicitly on analyzing the "fit" and experiences of historically underrepresented groups, including women, within predominantly white postsecondary institutions. For instance, while Hall and Sandler (1984) examined the "chilly" state of faculty life for female scholars within the maledominated field of higher education, D.H. Smith (1981) interrogated the "social and academic environments into which Black students matriculate on predominately white campuses" (p. 300) so as to understand how these environments affect Black students' development, persistence, and graduation rates. Allen (1985) analyzed whether African American students' success while attending predominantly white campuses hinged on student's own individual characteristics or institutional characteristics. D.G. Smith (1989) proposed the need for colleges and universities to re-evaluate their traditionally majoritarian practices in order to foster more inclusive environments capable of accommodating a changing student demographic. Even decades later, much of this early campus climate scholarship continues to have relevancy.

Among the many contributions of campus climate scholarship is the knowledge that, while there are common elements of institutional climate, the construction of individual campus environments is context specific, varying from institution to institution. In addition, within each institution, climate is made-up of multiple dimensions, including an institution's historic legacy, the compositional make-up of campus constituencies, psychological attitudes and practices—especially concerning racial/ethnic tension and discrimination, behavioral practices related to social integration and engagement, and 
organizational and structural practices—such as institutional policies around curriculum, budget allocation, and hiring, promotion, and tenure, among others (Hurtado, et al., 2012; Hurtado, et al., 1998, 1999; Milem, et al., 2005). Each of these dimensions, in turn, are informed by factors such as an institution's mission, size and type, as well as their funding and organizational governance structures. Indeed, as explained by Hurtado et al. (2012) these "microsystems," "mesosystems," "exosystems," and "macrosystems" (p.48) all help "comprise the campus climate for diversity" (Hurtado et al., 2012, p. 49).

Manning (2013) posits that the "organized anarchy" nature of higher education, which includes the need to be responsive to "multiple realities" complicates how institutions react to competing interests. With respect to addressing campus climate issues, colleges and universities continue to operate in reactive rather than proactive fashion. For these reasons I believe there is room to complicate existing campus climate binaries. In response, I offer the adoption of a health metaphor. I propose that rather than the existing popular binary terms of "chilly/welcoming" and "positive/negative" to describe and/or gauge climate, a health metaphor better captures and conveys the complexity and urgency behind addressing and monitoring campus climate. Existing paradigms prevalent in the analysis of campus climate are deeply engrained. As a figure of speech "climate" naturally lends itself to environmental/ weather-based analogies (Somers, Cofer, Austin, Inman, Martin, Rook, Stokes, \& Wilkinson, 1998). In addition, the dualism of positive/negative remains useful, especially when applied to the assessment and impact of campus climate variables, such as those measured across both institutional and population-specific survey instruments. 
I posit that a health metaphor is more apropos to conveying the need to respond to campus climate issues with timely and deliberate intervention(s). In other words, a health metaphor urges a move beyond just documenting the problem to treating the problem (Ahmed, 2007). Furthermore, a health metaphor directly reflects the growing body of research literature examining the real physiological and psychological effects of unhealthy campus climates for historically minoritized groups, especially at predominantly white institutions. Before reviewing what the application of a health metaphor on campus climate might look like, I first take time to revisit research on the detrimental health effects of white supremacy and racism.

\section{The Effects of Racism on Health}

Researchers have long studied the impact of racism on physiological and psychological health outcomes. Despite the fact that race is a social rather than biological construction (Bonilla-Silva, 2003; Gould, 1996; López, 1996; Marable, 2003; Omi \& Winant, 1994, 2015; Williams, 1997), studies prove that there are real tangible differences in morbidity and mortality rates along racial and ethnic lines (Williams, 1997; Williams \& Mohammed, 2009). Citing Kung, Hoyert, Xu, and Murphy (2008), Williams and Mohammed (2009) explain that among the "15 leading causes of death including heart disease, cancer, stroke, diabetes, kidney disease, hypertension, liver cirrhosis and homicide, African Americans [and other minoritized groups] have higher death rates" ( $p$. 20) in comparison to their white counterparts. And while the argument can be made that class is as important an indicator as race in determining health and life expectancy, the decisive power of racism on health outcomes is incontrovertible. For example, infant mortality rates for African American women with college degrees far outpace infant 
Journal Committed to Social Change on Race and Ethnicity | 2016

mortality rates for white, Latina, Asian and Pacific Islander women with no high school degree (Pamuk, Heck, \& Rueben, 1998). As this example makes clear, the overwhelming power of race and racism is so determinative that it has the capacity to nullify socioeconomic status.

The effects of racism are equally as pronounced on mental health (Carter, 2007; Harrell, 2000; Sellers, Caldwell, Schmeelk-Cone, \& Zimmerman, 2003). Dr. Chester Pierce's work on the psychological effects of racism on health has proven to be critically influential to contemporary scholarship, both within and beyond the medical field. Pierce, former Emeritus Professor of Education and Psychiatry at Harvard Medical School, framed racism as a disease in need of treatment. He explained, "[Racism] is a public health, mental health, perceptual, contagious, nutritional and lethal disease. The ubiquity of this disease defines its dimensions as a social problem" (Pierce, 1977, p. 5). Pierce also clarified that in its ubiquity, racism operates in a number of ways, not just through blatant acts of hostility but also in much more subtle but equally stunning ways. Pierce (1970) posited that while these subtle slights, which he termed "microaggressions" or "offensive actions," may appear minor or unimportant, their cumulative effect is nonetheless dangerous and crippling. He observed, "In and of itself a microaggression may seem harmless, but the cumulative burden of a lifetime of microaggressions can theoretically contribute to diminished mortality, augmented morbidity, and flattened confidence" (Pierce, 1974, p. 516). Pierce (1977) later added that there are three "essential dynamics for the continuation of racism," including "offensive mechanisms, micro-aggressions and kinetic messages" (p. 10). As Pierce's scholarship made clear, racism has the capacity to imbue every facet of life in 
Journal Committed to Social Change on Race and Ethnicity | 2016

conscious and unconscious fashion and through ordinary incidences. Pierce's work has proven to be extremely influential to critical postsecondary scholars seeking to understand the intersectional (Crenshaw, 1989,1993) experiences of historically underrepresented groups within college and university settings.

Solórzano (1998) was among the first to adapt Pierce's work to the study of higher education. Utilizing a CRT lens, Solórzano undertook a critical examination of both racial and gender microaggressions as experienced by Chicana and Chicano scholars during their doctoral study. His work underscores the importance of analyzing race beyond the Black and White paradigm, as well as the need to examine both racial and gender microaggressions "at each point in the educational system" (Solórzano 1998, p. 132). While Solórzano does not employ the term campus climate in his study, his examination of how racial and gender microaggressions affect the career paths of Chicana/o scholars undoubtedly speaks to the multidimensional factors shaping Chicana/o students' postsecondary experiences.

Since Solórzano's early work, the application of Pierce's microaggression framework to the study of postsecondary education is robust and growing (McCabe, 2009; Pittman, 2012; Smith, Allen, \& Danley, 2007; Solórzano, Allen, \& Carroll, 2002; Solórzano, Ceja, \& Yosso, 2000; Sue, Bucceri, Lin, Nadal, \& Torino, 2007; Yosso, Smith, Ceja, \& Solórzano, 2009). Pierce's framework has proven especially useful to examining how historically underrepresented groups, including students and faculty, experience their postsecondary environments. The proliferation of this scholarship also serves to underscore the fact that adopting an analogy of health in the study of campus climate is natural and instructive. 
Journal Committed to Social Change on Race and Ethnicity | 2016

\section{Complicating the Binary: Coupling Campus Climate with Health}

Pairing campus climate with health is not a novel concept per se. Davis (1998) was among the first to acknowledge that one of the greatest challenges facing postsecondary institutions lay in developing and fostering a healthy campus environment for all students. Since then, many more studies have employed the concept of striving towards a "healthy" campus climate to offer guidance and insight on the need to produce an optimally functioning and highly inclusive environment for all campus constituents (Bryant, 2007; Park, Denson, \& Bowman, 2013; Sullivan, Reichard \& Shumate, 2005; Vacarro, 2010; Zahorski, 2002). Still, as a whole the health metaphor is implied and under-theorized, remaining on the periphery of campus climate scholarship.

Adopting an analogy of health writ large when addressing campus climate issues is much more natural than it may appear. Ironically, such a frame would mirror and compliment the copious body of research literature already being produced by critical scholars seeking to illuminate the experiences of historically minoritized groups in higher education (Franklin, Smith, \& Hung, 2014; Pérez Huber \& Solórzano, 2015; Solórzano, 1998; Solórzano, Allen, \& Carroll, 2000; Solórzano, Ceja, \& Yosso, 2002; Sue, 2010; Sue, Bucceri, Lin, Nadal, \& Torino, 2009). Indeed, critical postsecondary scholars are already utilizing a health framework to explain how the historical, compositional, behavioral, psychological, and organizational dimensions of institution's climate influence and shape students' experiences in higher education. For instance, studies by Gildersleeve, Croom, and Vasquez (2011), Troung and Museus (2012), and Troung, Museus, and McGuire (2016) explicitly address students' experiences with 
Journal Committed to Social Change on Race and Ethnicity | 2016

psychological stress and racial trauma during their doctoral study. Likewise, building on Pierce's seminal work on microaggressions, Smith, Allen, Danley (2007) pioneered the concept of racial battle fatigue to speak to the psychological toll that Black males experience when attending predominately white postsecondary institutions. In addition, Sullivan $(2013 ; 2014)$ has written about how racism and white supremacy contribute to the disparate physiological and psychological health outcomes for historically underrepresented groups in higher education.

To be clear, students are not the only victims of the psychological stress and racial trauma perpetuated within predominantly white postsecondary institutions. Scholarship abounds (Delgado Bernal \& Villalpando, 2002; Gutiérrez y Muhs et al., 2013; Jayakumar, Howard, Allen, \& Han, 2009; Patton \& Catching, 2009; Pittman, 2012; Stanley, 2006; Turner, González, \& Wood, 2008) detailing the experiences of historically minoritized faculty in higher education. This research reveals that much like their students, minoritized faculty are susceptible to the same types of physiological and psychological trauma engendered within predominately white postsecondary institutions. In their review of 20 years of research literature on faculty of color in academe, Turner et al. (2008) suggest that there is much work to be done, across all dimensions of campus climate, to create "a more welcoming and affirming environment for faculty of color" (p. 158) in higher education.

As we stand on the cusp of preparing for the next wave of campus climate scholarship, one that accounts for the post-Black Lives Matter movement, adopting an analogy of health to frame issues of campus climate seems all the more timely and important. The urgency behind movements, like the Black Lives Matter movement, 
cannot be fully captured by descriptors such as "positive" or "negative." As the incidences that produced the protests in Ferguson and campuses across the country movement have proven, lives are at a stake.

As evidenced by this conceptual paper, my reasoning for proposing the adoption of a health analogy when framing issues of campus climate is multifaceted. Nevertheless, at its core, I believe that the application of a health metaphor to the examination of campus climate helps humanize its subjects, who are far too often nameless and voiceless. Adopting a metaphor of health to address issues of campus climate acknowledges that an institution's environment is not static; rather, like a living organism, it is responsive to surrounding stimuli. In addition, a health oriented climate framework also acknowledges that in order to maintain soundness and avoid crises, a healthy campus climate requires regular holistic monitoring and timely intervention as it adapts to an ever-changing context. A health metaphor is not meant to suggest a sterile and unattainable environment. Rather, campus climate framed through a lens of health, acknowledges that tension when handled appropriately can be beneficial. A health metaphor applied to the study of campus climate aims to humanize the experiences of historically minoritized bodies in higher education making explicit that differential physiological and psychological health outcomes are not the result of supposed individual (and historically racist) pathologies, but rather the product of the power and pathos of white supremacy in the system of higher education.

\section{Discussion}

I am cognizant that injecting the analogy of health into discussions of campus climate is a complicated task. The organizational structures of postsecondary 
Journal Committed to Social Change on Race and Ethnicity | 2016

institutions are complex, made even more so with diffused leadership models and systems of shared governance. Nevertheless, I argue that the application of a health metaphor when addressing issues of campus climate may be relevant to all dimensions of climate, including the historical, compositional, organizational, psychological, and behavioral.

For example, commenting on the academic culture of postsecondary institutions, Clark (1986) explained that within colleges and universities, "full-bodied ideologies [surrounding institutional saga—such as institutional symbols, stories, legends and beliefs] constitute moral capital" which can in turn be a "resource for institutional health" (p. 83), for good or bad. Brown-Nagin, Guinier, and Torres (2015), Gonzáles (2002), and Wilder (2014), among others, explain that the physical campus as well as the symbols celebrated therein carry very different meanings for majoritarian and minoritized people. Embedded in campus buildings, symbols, landmarks and memorials, postsecondary institutions project very different meanings; for some these might be innocuous parts of the institutional landscape, whereas for others these are visual representations of years of ingrained racism. For example, Wilder (2013) observes, "Campus folklore and place names record the story of slavery in college towns [home to many of the nation's oldest and most respected colleges and universities]. These local legends and landscapes are a diary of the long, intimate association between the academy and slavery" (p. 145). Castagno and Lee (2007) provide another example by problematizing the misuse of Native mascots and Indigenous cultural symbols in higher education. As they explain, although colleges and universities often frame their use of sacred symbols as a way of "honoring' Indigenous 
people" (Castagno \& Lee, 2007, p. 5) the reality can be quite opposite for Native people. Even so it often seems that the fiscal health of an institution, fattened by the sales of sports apparel and alumni donations, takes precedent over any potential trauma and distress experienced by Indigenous students, faculty, and staff (Castagno \& Lee, 2007).

Institutions would do well to be mindful and self-reflective of their institutional campus health, always interrogating how policies and practices, which on the surface may appear inoffensive, have the capacity to be injurious to historically minoritized populations. Indeed, as the research literature (Jayakumar, 2015) makes clear that the mere presence of a racially diverse student body does not in itself produce a healthy campus climate. Equally important to the presence of a diverse student, faculty, and staff body are equitable policies and practices that support persistence and success (Bensimon, 2005; Dowd \& Bensimon, 2015). Hypothetically, a homogenous institution that approaches issues of race and diversity through a critical and social justice oriented lens may be capable of fostering a healthy climate.

The adoption of a health metaphor in the study and analysis of campus climate will not in itself expunge all racist sagas and artifacts. However, we can at least work on treating endemic racism by validating its presence and adopting equity-minded practices (Bensimon, 2005; Dowd \& Bensimon, 2015). For example, Bell (1991) suggests that while change and progress may appear overwhelming and unattainable, accepting the reality of racial realism is in itself a critical first step. He explains,

You may think, "it is easy to criticize, but what would you suggest?" At the least, I think we should adopt the medical professions' creed: "First, do no harm." We all know better than to think racial subordination can be ended tomorrow. (p. 91) 
Journal Committed to Social Change on Race and Ethnicity | 2016

I recognize that some might argue that Bell's prescription is perhaps too simplistic, and that is much work to do to eliminate all vestiges of racism and white supremacy in higher education. Still, I echo Bell's suggestion. Postsecondary institutions would do well to ensure that their campus constituents are not further victimized by their own institutional malpractice. My hope is that by complicating the campus climate binary we can strive towards making postsecondary environments more humane for historically minoritized bodies. 


\section{References}

Ackelsberg, M., Hart, J., Miller, N.J., Queeny, K. \& Van Dyne, S. (2009). Faculty microclimate change at Smith College. In W. Brown-Glaude (Ed.), Doing diversity in higher education: Faculty leaders share challenges and strategies (pp.83-102). New Brunswick, NJ: Rutgers University Press.

Ahmed, S. (2007). 'You end up doing the document rather than doing the doing': Diversity, race equality and the politics of documentation. Ethnic and Racial Studies, 30(4), 590-609.

Allen, W.R. (1985). Black student, white campus: Structural, interpersonal, and psychological correlates of success. The Journal of Negro Education, 54(2), 134147.

Antonio, A. L. (2001). The role of inter-racial interaction in the development of leadership skills and cultural knowledge and understanding. Research in Higher Education, 42(5), 593-617.

Antonio, A. L. (2004). Diversity and the influence of friendship groups in college. The Review of Higher Education, 25(1), 63-89.

Antonio, A. L., Chang, M. J., Hakuta, K., Kenny, D. A., Levin, S., \& Milem, J. F. (2004). Effects of racial diversity on complex thinking in college students. Psychological Science, 15(8), 507-510.

Bell, D. A. (1980). Brown v. Board of Education and the Interest-Convergence Dilemma. Harvard Law Review, Vol. 93, 518-533.

Bell, D. A. (1987). And we are not saved. New York: Basic Books, Inc.

Bell, D.A. (1989). And we are not saved: The elusive quest for racial justice. New York: BasicBooks.

Bell, D. A. (1991). Racism is here to stay: Now what? Howard Law Journal, 35, pp.7993.

Bell, D. A. (1992). Faces at the bottom of the well: The permanence of racism. New York: BasicBooks.

Bell, D. A. (2004). Silent covenants: Brown v. Board of Education and the unfulfilled hopes for racial reform. New York: Oxford University Press.

Bell, D. A. (2005a). The unintended lessons in Brown v. Board of Education. New York 
Law School Law Review, 49, 1053-1067.

Bell, D. A. (2005b). Racial realism. In R. Delgado \& J. Stefancic (Eds.), The Derrick Bell reader (pp.55-96). New York: Oxford University Press.

Bensimon, E. M. (2005). Equality as a fact, equality as a result: A matter of institutional accountability. American Council of Education.

Berrett, D. \& Hoover, E. (2015, Nov 13). When pursuing diversity, victory is hard to define. The Chronicle of Higher Education. Retrieved from http://chronicle.com/article/When-Pursuing-Diversity/234190?cid=cp15

Bonilla-Silva, E. (2003). Racism without racists: Color-blind racism and the persistence of racial inequality in the United States. Lanham, MD: Rowman \& Littlefield Publishers, Inc.

Brown-Nagin, T., Guinier, L., \& Torres, G. (2015). Tejas es differente: UT Austin's admissions program in light of its exclusionary history. In U.M. Jayakumar \& L.M. Garces (Eds.) Affirmative action and racial equity: Considering the Fisher case to forge a path ahead (pp.63-79). New York: Routledge.

Bryant, A. N. (2007, January). A portrait of evangelical Christian students in college. In Social Science Research Council's Essay Forum on the Religious Engagements of American Undergraduates (p. 2).

Carnevale, A.P. \& Strohl, J. (2013). Separate \& unequal: How higher education reinforces the intergenerational reproduction of white racial privilege. Washington, DC: Georgetown University Center on Education and the Workforce.

Carter, R. T. (2007). Racism and psychological and emotional injury recognizing and assessing race-based traumatic stress. The Counseling Psychologist, 35(1), 13105.

Chang, M. J. (2001). The positive educational effects of racial diversity on campus. In G. Orfield with M. Kurlaender (Eds.) Diversity challenged: Evidence on the impact of affirmative action (pp.175-186). Cambridge, MA: President and Fellows of Harvard College.

Chang, M. J., Denson, D., Saenz, V., Misa, K. (2006). The educational benefits of sustaining cross-racial interaction among undergraduates. Journal of Higher Education, 77(3), 430-455. 
Clark, B. R. (1986). The higher education system: Academic organization in crossnational perspective. Berkeley, CA: University of California Press.

Crenshaw, K. (1989). Demarginalizing the intersection of race and sex: A Black feminist critique of antidiscrimination doctrine, feminist theory and antiracist politics. University of Chicago Legal Forum, 1989, 139-167.

Crenshaw, K. (1993). Mapping the margins: Intersectionality, identity politics, and the violence against women of color. Stanford Law Review, 43, 1241-1299.

Crenshaw, K.W. (2011). Twenty years of Critical Race theory: Looking back to more forward. Connecticut Law Review, 43(5), 1253-1353.

Crenshaw, K., Gotanda, N., Peller, G., \& Thomas, K. (Eds.). (1995). Critical race theory: The key writings that formed the movement. New York: New Press.

Cress, C.M., \& Ikeda, E.K. (2003). Distress under duress: The relationship between campus climate and depression in Asian American students. Journal of Student Affairs Research and Practice, 40(2), 74-97.

Davis, W. M. (1998). Toward civility: Assessment as a means toward improving campus climate. College Student Affairs Journal, 18(1), 72-84.

Delgado, R., \& Stefancic, J. (2012). Critical race theory: An introduction (2nd Ed.). New York: New York University Press.

Delgado Bernal, D., \& Villalpando, O. (2002). An apartheid of knowledge in academia:

The struggle over the" legitimate" knowledge of faculty of color. Equity \&Excellence in Education, 35(2), 169-180.

Dowd, A.C. \& Bensimon, E.M. (2015). Engaging the "race question": Accountability and equity in U.S. higher education. New York: Teachers College Press.

Du Bois, W.E.B. (1935). Does the Negro need separate schools? In E.J. Sundquist (Ed.), The Oxford W.E.B. Du Bois Reader (pp. 423-431). New York: Oxford.

Feagin, J. R., Vera, H., \& Imani, N. (1996). The agony of education: Black students at White colleges and universities. New York: Routledge.

Fisher v. University of Texas at Austin, 133 U.S. 2411 (2013).

Franklin, J. D., Smith, W. A., \& Hung, M. (2014). Racial battle ratigue for Latina/o students a quantitative perspective. Journal of Hispanic Higher Education, 1538192714540530 . 
Gildersleeve, R. E., Croom, N. N., \& Vasquez, P.L. (2011). "Am I going crazy?!": A critical race analysis of doctoral education Equity \& Excellence in Education, 44(1), 93-114.

Goldberg, D.T. (2015). Are we all postracial yet?: Debating Race. Malden, MA: Polity.

Gonzalez, K. P. (2003). Campus culture and the experiences of Chicano students in a predominantly White university. Urban Education, 37(2), 193-218.

Gould, S.J. (1996). The mismeasure of man. New York: W.W. Norton \& Company, Inc. Gratz v. Bollinger et al., 539 U.S. 244 (2003).

Grodsky, E. \& Kurleander, M. (2010). Equal opportunity in higher education: The past and future of California's proposition 209. Cambridge, MA: Harvard Education Press.

Grutter v. Bollinger et al., 539 U.S. 203 (2003).

Gurin, P., Dey, E. L., Hurtado, S., \& Gurin, G. (2002). Diversity in higher education: Theory and impact on educational outcomes. Harvard Educational Review, 72(3), 330-366.

Gutiérrez y Muhs, G., Neimann, Y. F., Gonzalez, C. G., Harris, A. P. (2013). Presumed incompetent: The intersections of race and class for women in academia. Logan, UT: Utah State University Press.

Hall, R. M. \& Sandler, B. R. (1984). Out of the classroom: A chilly campus climate for women? Washington, D.C.: Association of American Colleges. Retrieved from http://files.eric.ed.gov/fulltext/ED254125.pdf

Harper, S.R. (2012). Race without racism: How higher education researchers minimize racist institutional norms. The Review of Higher Education, Vol. 36 (No.1), pp. 929.

Harper, S.R. \& Hurtado, S. (2007). Nine themes in campus racial climates and implications for institutional transformation. New Directions for Student Services, 120, 7-24.

Harrell, S. P. (2000). A multidimensional conceptualization of racism - related stress: Implications for the well-being of people of color. American journal of Orthopsychiatry, 70(1), 42-57.

Hopwood v. Texas, 78 F3d 932, 944 (5th Cir. 1996). 
Journal Committed to Social Change on Race and Ethnicity | 2016

Hurtado, S. (1992). The campus racial climate: Contexts of conflict. Journal of Higher Education, 63(5), 539-569.

Hurtado, S. (2001). Diversity and learning for a pluralistic democracy. In W. Allen, M. Bonous-Hammarth, \& R. Teranishi, (Eds.), Higher education in a global society: Achieving diversity, equity, and excellence (pp. 249-267). Oxford, England: Elsevier.

Hurtado, S., Alvarez, C. L., Guillermo-Wann, C., Cuellar, M., \& Arellano, L. (2012). A model for diverse learning environments. In J. C. Smart \& M. B. Paulsen (Eds.), Higher education: Handbook of theory and research, (pp. 41-122). Dordrecht, Netherlands: Springer Publishing.

Hurtado, S., Milem, J. F., Clayton-Pedersen, A. R., \& Allen, W. R. (1998). Enhancing campus climates for racial/ethnic diversity: Educational policy and practice. The Review of Higher Education, 21(3), 279-302.

Hurtado, S., Milem, J. F., Clayton-Pedersen, A. R., \& Allen, W. R. (1999). Enacting diverse learning environments: Improving the campus climate for racial/ethnic diversity in higher education. ASHE-ERIC Higher Education Reports Series 26(8). San Francisco: Jossey Bass.

Hurtado, S., Carter, D. F., \& Kardia, D. (1998). The climate for diversity: Key issues for institutional self-study. New Directions for Institutional Research, 98, 53-63.

Jayakumar, U. M. (2008). Can higher education meet the needs of an increasingly diverse and global society? Campus diversity and cross-cultural workforce competencies, Harvard Educational Review, 78(4), 615-651.

Jayakumar, U. M., Howard, T. C., Allen, W. R., \& Han, J. C. (2009). Racial privilege in the professoriate: An exploration of campus climate, retention, and satisfaction. The Journal of Higher Education, 80(5), 538-563.

Jayakumar, U. M., \& Museus, S. D. (2012). Mapping the intersection of campus cultures and equitable outcomes among racially diverse student populations. In S.D. Museus \& U.M. Jayakumar (Eds.) Creating campus cultures: Fostering success among racially diverse student populations, (pp.1-27). New York: Routledge. 
Jayakumar, U. M. (2015). The shaping of postcollege colorblind orientation among Whites: Residential segregation and campus diversity Experiences. Harvard Educational Review 85(4), pp. 609-645.

Johnston, A. (2015, December 18). Student protests, then and now: From "hey, hey LBJ!" to "Black lives matter!" The Chronicle of Higher Education: The Chronicle Review, B6-B7.

Kahlenberg, R. D. (1997). The remedy: Class, race, and affirmative action. Basic Books. Karabel, J. (2005). The chosen: The hidden history of admission at Harvard, Yale, and Princeton. New York: Houghton Mifflin Company.

Kidder, W. C., \& Gándara, P. (2015). Two decades after the affirmative act ban: Evaluating the University of California's race-neutral efforts. Retrieved from http://www.ets.org/Media/Research/pdf/kidder_paper.pdf

Long, M. C. (2007). Affirmative action and its alternatives in public universities: What do we know?. Public Administration Review, 67(2), 315-330.

Long, M. C., \& Tienda, M. (2008). Winners and losers: Changes in Texas university admissions post-Hopwood. Educational Evaluation and Policy Analysis, 30(3), 255-280.

López, I. F. H. (1996). White by law: The legal construction of race. New York: New York University Press.

López, I. F. H. (2010). Post-racial racism: Racial stratification and mass incarceration in the age of Obama. California Law Review, 98(3), 1023-1074.

Manning, K. (2013). Organizational theory in higher education. New York: Routledge.

Marable, M. (2003). The great wells of democracy: The meaning of race in American life. New York: Basic Books.

McCabe, J. (2009). Racial and gender microaggressions on a predominantly-White campus: Experiences of Black, Latina/o and White undergraduates. Race, Gender \& Class, 16, 133-151.

McWhorter, J. (2008). Racism is over in America. Retrieved from http://www.forbes.com/2008/12/30/end-of-racism-opedcx_jm_1230mcwhorter.html 
Journal Committed to Social Change on Race and Ethnicity | 2016

McWhorter, J. (2010). It's official: America is 'post-racial' in the age of Obama.

Retrieved from https://www.manhattan-institute.org/html/its-official-america-postracial-age-obama-2322.html

Milem, J. F., Chang, M. J., \& Antonio, A. L. (2005). Making diversity work on campus: A research-based perspective. Washington, DC: Association American Colleges and Universities.

Museus, S. D., Ledesma, M. C., \& Parker, T. L. (2015). Racism and racial equity in higher education. ASHE Higher Education Report: Volume 42 (1). San Francisco: Jossey Bass.

Omi, M. \& Winant, H. (1994). Racial formation in the United States: From the 1960s to the 1990s. New York: Routledge.

Omi, M. \& Winant, H. (2015). Racial formation in the United States (Third Edition). New York: Routledge.

Orfield, G. (Ed.). (2001). Diversity Challenged: Evidence on the Impact of Affirmative Action. Cambridge, MA: Harvard Education Publishing Group.

Orfield, G., \& Miller, E. (Eds.). (1998). Chilling Admissions: The Affirmative Action Crisis and the Search for Alternatives. Cambridge, MA: Harvard Education Publishing Group.

Pamuk, E., Makuk, S., Heck, K., \& Reuben, C. (1998). Socioeconomic status and health chartbook. Hyattsville, MD: National Center for Health Statistics.

Park, J. J., Denson, N., \& Bowman, N. A. (2012). Does socioeconomic diversity make a difference? Examining the effects of racial and socioeconomic diversity on the campus climate for diversity. American Educational Research Journal, 50(3), 466-496.

Patton, L. D., \& Catching, C. (2009). 'Teaching while Black': narratives of African American student affairs faculty. International Journal of Qualitative Studies in Education, 22(6), 713-728.

Pérez Huber, L., \& Solórzano, D. G. (2015). Racial microaggressions as a tool for critical race research. Race Ethnicity and Education, 18(3), 297-320.

Pierce, C. (1970). Offensive mechanisms. In F. Barbour (Ed.), The Black seventies (pp. 265-282). Boston: Porter Sargent. 
Pierce, C. (1974). Psychiatric problems of the Black minority. In S. Arieti (Ed.), American handbook of psychiatry (pp. 512-523). New York: Basic Books.

Pierce, C. (1975). The mundane extreme environment and its effects on learning. In S. Brainard, (Ed). Learning disabilities: Issues and recommendations for research. Washington, D.C.: Institute of Education, 1-23.

Pierce, C. M. (1977). Group Dynamics in Minority Groups in Inner City Environments. Cambridge, MA: Harvard University, Graduate School of Education. Retrieved from

http://oai.dtic.mil/oai/oai?verb=getRecord\&metadataPrefix=html\&identifier=ADA0 41020

Pittman, C. T. (2012). Racial microaggressions: The narratives of African American faculty at a predominantly White university. The Journal of Negro Education, 8292.

Potok, M. (2016). The year in hate and extremism. Retrieved from https://www.splcenter.org/fighting-hate/intelligence-report/2016/year-hateandextremism

Rankin, S.R. \& Reason, R.D. (2005). Differing perceptions: How students of color and white students perceive campus climate for underrepresented groups. Journal of College Student Development, 46(1), 43-61.

Riffkin, R. (2015). Racism edges up again as most important U.S. problem. Retrieved from http://www.gallup.com/poll/184193/racism-edges-again-importantproblem.aspx?g_source=race\&g_medium=search\&g_campaign=tiles

Sellers, R. M., Caldwell, C. H., Schmeelk-Cone, K. H., \& Zimmerman, M. A. (2003). Racial identity, racial discrimination, perceived stress, and psychological distress among African American young adults. Journal of Health and Social Behavior, 302-317.

Sheriff, N. (2015). US cited for police violence, racism in scathing UN review on human rights. Aljazeera America. Retrieved from http://america.aljazeera.com/articles/2015/5/11/us-faces-scathing-un-review-onhuman-rights-record.html 
Smith, D.H. (1981). Social and academic environments of Black students on white campuses. Journal of Negro Education, 50(3), 299-306.

Smith, D.G. (1989). The challenge of diversity: Involvement or alienation in the academy? ASHE-ERIC Higher Education Report No. 5. Washington, D.C.: ASHE-ERIC Higher Education Reports, The George Washington University. Retrieved from http://files.eric.ed.gov/fulltext/ED314987.pdf

Smith, D. G. (2011). Diversity's promise for higher education: Making it work. Baltimore, MA: Johns Hopkins University Press.

Smith, D. G. (2015). Diversity's promise for higher education: Making it work (2nd Ed.). Baltimore, MA: Johns Hopkins University Press.

Smith, W. A., Allen, W. R., \& Danley, L. L. (2007). "Assume the Position... You Fit the Description": Psychosocial Experiences and Racial Battle Fatigue Among African American Male College Students. American Behavioral Scientist, 51(4), 551-578.

Stanley, C. A. (2006). Coloring the academic landscape: Faculty of color breaking the silence in predominantly White colleges and universities. American Educational Research Journal, 43(4), 701-736.

Steele, C. (1999). A threat in the air: How stereotypes shape intellectual identity and performance. American Psychologist, 52(6), 613-629.

Steele, C. M. (2010). Whistling Vivaldi. New York: WW Norton \& Co.

Sue, D. W. (2010). Microaggressions in everyday life: Race, gender, and sexual orientation. John Wiley \& Sons.

Sue, D. W., Bucceri, J., Lin, A. I., Nadal, K. L., \& Torino, G. C. (2009). Racial microaggressions and the Asian American experience. Cultural Diversity and Ethnic Minority Psychology, 13(1), 72-81.

Sullivan, L. G., Reichard, D. L., \& Shumate, D. (2005). Using campus climate surveys to foster participatory governance. Community College Journal of Research \& Practice, 29(6), 427-443.

Sullivan, S. (2013). Inheriting racist disparities in health: Epigenetics and the transgenerational effects of white racism. Critical Philosophy of Race, 1(20), 190218. 
Sullivan, S. (2014). The hearts and guts of white people: Ethics, ignorance, and the physiology of white racism. Journal of Religious Ethics, Inc, 591-611.

Solórzano, D.G. (1998). Critical race theory, race and gender microaggression, and the experience of Chicana and Chicano scholars. Qualitative Studies in Education, 11(1), 121-136.

Solórzano, D., Allen, W. R., \& Carroll, G. (2002). Keeping race in place: Racial microaggressions and campus racial climate at the University of California, Berkeley. Chicano-Latino L. Rev., 23, 15.

Solórzano, D., Ceja, M., \& Yosso, T. (2000). Critical race theory, racial microaggressions, and campus racial climate: The experiences of African American college students. Journal of Negro Education, 60-73.

Somers, P., Cofer, J., Austin, J. L., Inman, D., Martin, T., Rook, S., Stokes, T. \& Wilkinson, L. (1998). Faculty and staff: The weather radar of campus climate. New Directions for Institutional Research, 1998(98), 35-52.

Thelin, J. R. (2004). A history of American higher education. Baltimore, MD: John Hopkins University Press.

Thernstrom, S. \& Thernstrom, A. (1997). America in black and white: One nation, indivisible. New York: Touchstone.

Troung, K. A. \& Museus, S. D. (2012). Responding to racism and racial trauma in doctoral study: An inventory of coping and mediating relationships. Harvard Educational Review, 82(2), 226-254.

Truong, K. A., Museus, S. D., \& McGuire, K. M. (2016). Vicarious racism: a qualitative analysis of experiences with secondhand racism in graduate education. International Journal of Qualitative Studies in Education, 29(2), 224247.

Turner, C. S. V., González, J. C., \& Wood, J. L. (2008). Faculty of color in academe: What 20 years of literature tells us. Journal of Diversity in Higher Education, 1(3), 139.

WeTheProtestors (2015). The demands. Retrieved from http://www. TheDemands.org/ Wilder, C. S. (2014). Ebony and ivy: Race, slavery, and the troubled history of America's universities. New York: Bloomsbury Publishing USA. 
Williams, D. R. (1997). Race and health: basic questions, emerging directions. Annals of Epidemiology, 7(5), 322-333.

Williams, D. R., \& Mohammed, S. A. (2009). Discrimination and racial disparities in health: evidence and needed research. Journal of Behavioral Medicine, 32(1), 20-47.

Yosso, T.J., Parker, L., Solórzano, D.G., \& Lynn, M. (2004). From Jim Crow to affirmative action and back again: A critical race discussion of racialized rationales and access to higher education. Review of Research in Education, 28, $1-25$.

Yosso, T., Smith, W., Ceja, M., \& Solórzano, D. (2009). Critical race theory, racial microaggressions, and campus racial climate for Latina/o undergraduates. Harvard Educational Review, 79(4), 659-691. 